\title{
Urban Sustainability Performance Measurement of a Small Brazilian City
}

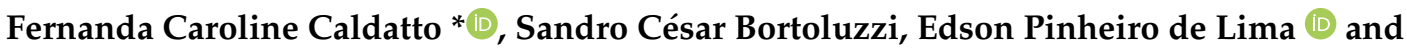 \\ Sergio E. Gouvea da Costa (1)
}

Industrial and Systems Engineering, Universidade Tecnológica Federal do Paraná, Pato Branco CEP 85503-390, Brazil; sandro@utfpr.edu.br (S.C.B.); pinheiro@utfpr.edu.br (E.P.d.L.); gouvea@utfpr.edu.br (S.E.G.d.C.)

* Correspondence: fercaldatto@gmail.com

Citation: Caldatto, F.C.;

Bortoluzzi, S.C.; Pinheiro de Lima, E.; Gouvea da Costa, S.E. Urban Sustainability Performance Measurement of a Small Brazilian City. Sustainability 2021, 13, 9858. https://doi.org/10.3390/su13179858

Academic Editor: Paolo Renna

Received: 28 July 2021

Accepted: 18 August 2021

Published: 2 September 2021

Publisher's Note: MDPI stays neutral with regard to jurisdictional claims in published maps and institutional affiliations.

Copyright: (c) 2021 by the authors. Licensee MDPI, Basel, Switzerland. This article is an open access article distributed under the terms and conditions of the Creative Commons Attribution (CC BY) license (https:// creativecommons.org/licenses/by/ $4.0 /)$.

\begin{abstract}
The population increase in cities implies the need to balance environmental, social, and economic demands in such a way that growth is guided by sustainable development. This research aimed to build a model for evaluating the performance of urban sustainability in a small Brazilian city. To structure the model, the multicriteria decision support methodology-constructivist (MCDA-C) was adopted, which aims to identify the objectives and criteria of a context based on the actors' values. The measurement model resulted in 66 criteria, which were measured by considering the reference levels (Good and Neutral). The results of the analysis through the model showed that the city's urban sustainability performance was good in 45 criteria, excellent in 20 , and compromising in 1 . Thus, there is a theoretical contribution by presenting a multi-criteria performance assessment methodology focused on the sustainability of small towns and practice by helping to formulate and evaluate public policies. In addition, when confronting the criteria of the model built with the objectives of the Sustainable Development Goals (SDGs), it was identified that, although they are partially aligned, the improvement of performance in local sustainability has positive effects on achieving global goals.
\end{abstract}

Keywords: performance measurement; urban sustainability; MCDA-C; sustainable development; problem structuring

\section{Introduction}

With the expansion of cities, several environmental, social, and economic problems have begun to emerge [1]. The existence of slums, the low quality of life of the population, the reduction of natural resources, air pollution, and low levels of economic development are some examples [2]. This reality can be identified in the most varied sizes of cities [3] when sustainable urban development is not pursued.

The most widespread definition for sustainable development was given by the World Commission on Environment and Development and consists of a guarantee that the current generation can meet their needs without harming future generations [4]. The achievement of sustainability is conditioned on a balanced and dynamic system of the three pillars: environmental, social, and economic [1,5-7]. According to [2], in urban sustainability, the three dimensions can be worked on in situations related to aspects of people's lives, such as education, culture and health, waste treatment, city vegetation, discharge of polluting gases, quality and the growth of the economy, and the reduction of waste.

However, achieving sustainable development is not a trivial task. There are limiting factors in the process that need to be considered, which are: Technical capacity (knowledge, experience and training), low political commitment, financial resources [8], and citizens' knowledge [3]. In addition, the adoption of beneficial actions for only one dimension or, that which promotes sectoral interests at the expense of others, should be avoided [9], as sacrificing the performance of one dimension to achieve better performance in another 
contradicts the nature of sustainable development $[2,10]$. Sustainable urban development, therefore, presupposes a favorable performance for all three dimensions.

Aiming to expand the engagement of countries in achieving sustainable development, the United Nations Development Programme (UNDP) created an agenda with global objectives to be achieved by the year 2030 [11]. The Sustainable Development Goals (SDGs), as they are called, provide a framework of goals and indicators to support planning and reporting [12]. However, its conception does not foresee issues caused by local needs, therefore the modification or proposal of alternative indicators has been suggested, increasing its usefulness in the monitoring of efforts and achievements related to the SDGs [13].

Therefore, considering that the goals of the SDGs were not conceived based on the uniqueness of each context, it is possible to make use of performance measures for monitoring, as they are the basis for performance measurement (PM) and facilitate planning and management [14]. Given the complexity of the urban context and the fact that it encompasses a variety of interrelated factors, PM needs to be dynamic and consider objective and subjective elements and the characteristics of a constructivist posture in order to increase the transparency, clarity, and understanding of the chosen criteria [15].

Consequently, it identifies the need to build a model of PM that allows for the monitoring of the progress of local sustainable development and serves as a support for the decision. Thus, the objective of this study was to identify the relevant criteria for the construction of a model for measuring the performance of urban sustainability in a small Brazilian city and monitoring the achievement of the SDGs. The work consisted of: Identifying the criteria to be considered in the PM model of urban sustainability, according to the objectives of the decision-making context in the design of local actors; Identifying the local contribution with which to monitor the achievement of the SDGs, based on the constructed model.

\section{Urban Sustainable Development Performance Assessment}

The complexity of cities and their socioeconomic and environmental phenomena represent a challenge for both science and politics $[6,16]$. Adopting a sustainable development policy clearly identifies to public managers: The changes needed to reach the goal; What should be measured; How to measure; Which criteria can be used for this assessment [10]. To assist in this process, they can make use of a PM model.

At first, PM was guided by traditional cost accounting and management control models. In the late 1980s, a process of parameter change began, with the emergence of new PM models [17]. In this period, more strongly between 1994 and 1996, the performance measurement "revolution" occurred, wherein the scientific community published more than 3000 articles on the subject [14].

Currently, in the literature, it has been noted that, when conducting PM, many researches are organized based on the selection of generic assessment criteria, that is, criteria which are selected from literature, other contexts, legislation, certification processes or other sources, without considering the particularities of each decision context [18]. Some examples of this pattern can be seen in models used to measure the sustainable urban development of European and Chinese cities, such as the examples below.

The model chosen by [2] to quantitatively assess the level of sustainability of the urbanization process in 20 Chinese agglomerations, for example, was composed of indicators emphasized by the NNUP (National New Urbanization Planning) [5]. In turn, and seeking to assess the level of sustainable urban development in Chinese cities, they adopted a comprehensive indicator method called the Full Permutation Polygon Synthetic Indicator, selecting indicators that allowed measurement from existing data. Other researchers, when building a model to assess the urban sustainability of European cities, selected indicators from 18 indexes and 7 indicator systems, using IndSelec and Delphi as instruments [7]. It has been noted that the PM models mentioned, as they were generated from existing models, did not have a rigorous enough structure to identify objectives that were unique to the context. 
In methodologies that adopt a constructivist stance, PM models are developed from the construction of knowledge about the objectives and criteria unique to the context and which fully considers the preferences and values of the actors involved in the decision $[15,18,19]$. Municipal planners and managers, situated between national governments and citizens, are essential actors in the transition process to sustainable cities $[13,20]$. When actors are able to visualize the problem, learning is generated through clear information that allows them to identify the impacts of possible actions [21].

The decision process starts with problem structuring [15]. This allows for the identification of the decision opportunities necessary for the creation of new alternatives and the assessment of the impact of actions [21], since objective and subjective elements are considered during the process [15]. Building a PM model of the urban system through a structured process implies a greater engagement of the actors involved in the decision-making process, as they become active in it.

A relevant factor in the process is the designation of good criteria, which have the following characteristics: Availability, understandability, credibility, manageability [22], relevance, consistency, and transparency [23]. The criteria should contribute to improving communication and reducing complexity [12], in addition to reflecting assessment priorities as well as lower priority issues that need to be resolved in the future [3].

Therefore, caution must be exercised when selecting criteria, and such a process must be consistent, transparent, consultative, and robust [12], since the criteria are a means of translating urban sustainability into measurable components [24] and must be built based on three dimensions: Environmental, economic, and social [16].

Another point that demands attention regarding the criteria is the weighting, which serves to quantitatively express the representativeness of a criterion in relation to the others [9]. The correct delimitation of the weight of each criterion guarantees the generation of integrated, dynamic, accessible, and visible performance information, enabling a proactive decision-making process, that is, one with agility and responsiveness [17].

All these factors justify the inexistence of a set of widely applicable criteria [25], despite the fact that many methods, techniques, and methodologies have been presented as an option to measure sustainable development in recent years [26]. This can be explained as, even if the models combine several criteria [27], each context demands a detailed analysis, which varies according to size and priority care needs [28].

A recurrent problem in the construction of a PM model is the lack of available data, which results in the exclusion of relevant criteria from the analyses [10,22,29]. This is a barrier often encountered, even in the analysis of urban sustainability based on the SDGs. In these cases, some researchers choose to evaluate the SDGs separately, as with SDG 11, relating to sustainable cities and communities [8,13], which has been considered a key element for the assessment, as it encompasses a greater range of factors for urban analysis, compared to indicators linked to the analysis of other SDGs [30].

For this reason, given the amount of information that involves urban sustainability, and seeking to minimize the damage caused by insufficient data, many studies have used the multicriteria methodology in PM. This methodology has been the basis for PM sustainability in different contexts, such as countries [29], cities [16,27], or specific factors such as the management of rainwater [31], transport [32], solid waste management [33], and quality of life [15].

Multicriteria decision aiding methodology-constructivist (MCDA-C) is considered a branch of the traditional MCDA, differing, however, in the initial structuring phase, which allows actors to expand their knowledge and identify the consequences of their preferences [34]. The fact of considering multiple objectives and allowing them to be sorted by priority, improving the quality of decisions and reducing uncertainties [32], allows the multi-criteria methodology to be applied in different contexts. Furthermore, as it allows new information to be added to the model during the process, it is considered robust and versatile [15]. Therefore, the construction of the PM model of urban sustainability present in this research was based on the MCDA-C. 


\section{Materials and Methods}

The construction of the PM model occurred from the application of the MCDA-C structuring phase, being conceived as a decision support methodology, according to the steps shown in Figure 1.

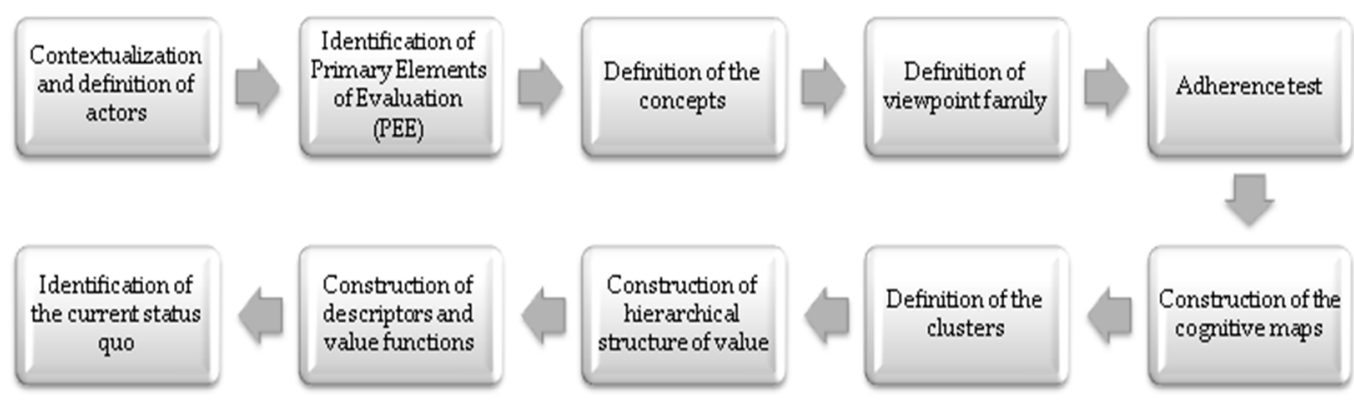

Figure 1. Procedures for building the model.

Considering the discovery of [5] that smaller cities have greater potential to improve overall performance in relation to sustainable development, the field study was carried out with the administration of a small city located in the south of Brazil-Coronel Vivida. According to [35], Brazilian cities with a population of up to 50,000 inhabitants are classified as small. In 2010, 4957 Brazilian municipalities (representing 89\% of the country's municipalities) had a population equal to, or less than, 50,000 inhabitants.

The city of Coronel Vivida is located in the mesoregion of southwestern Paraná, microregion of Pato Branco, $405 \mathrm{~km}$ away from the state capital, Curitiba. The city's administrative structure has 6 levels of hierarchical organization, but all are subordinate to the mayor.

In the last population survey, in 2010, Coronel Vivida had 21,749 inhabitants, of which 15,445 lived in the urban area and 6304 in the rural area, resulting in a demographic density of 31.78 inhab $/ \mathrm{km}^{2}$ [35]. The city's human development index (HDI) is 0,723 , and represents the socioeconomic reality of most of the Brazil's South Region quite well. The challenges that municipalities face in adjusting them to SDG demands are very similar, as the main industries are related to agrobusiness and livestock breeding.

As for its social issue, [36] identified an incidence of poverty of $42.1 \%$, while the Brazilian municipalities with the highest and lowest incidence had, respectively, $84 \%$ and $4.55 \%$. In relation to environmental issues, the city has dedicated attention to solid waste, especially with regard to the collection and disposal of waste produced, but other segments require improvements, which can be noticed through the PM.

The performance evaluation model built for the city of Coronel Vivida had the participation of several actors responsible for managing the city's sustainability. In total, 33 interviews were carried out in order to cover all stages of structuring in the PM model and all the departments involved. The protocol for conducting the field study is shown in Table 1.

The first stage of the structuring aimed to define and understand the decision-making context and the actors involved [37]. This was the first interview conducted with the municipal mayor to understand the problem (context) and other actors involved with the city's urban sustainability.

The second stage consisted of interviews with those responsible for the environment, industry and commerce, and health and social assistance departments to identify the primary elements of evaluation (PEE) through a brainstorming technique [38]. In the third stage, the interviews with the same actors were used to transform the EPAs into concepts (objectives), that is, for each PEE, a concept representing the decisionmaker's choice of preferred direction and the psychologically opposite pole were identified, which were separated by reticence, as provided for in the methodology, read as "instead of" [34]. It is 
important to stress that all stages were legitimized by the city's mayor as he was the main decisionmaker.

Table 1. Protocol for conducting the field study for the construction of the PM model.

\begin{tabular}{|c|c|c|c|}
\hline Stage of Structuring in the PM Model & Interview & Decider/Department & Duration \\
\hline 1-Contextualization & 1 & Mayor & $1 \mathrm{~h}$ \\
\hline \multirow{3}{*}{$\begin{array}{l}\text { 2-Identification of primary elements of } \\
\text { evaluation (PEE) }\end{array}$} & 2 & Environment and Solid Waste Department & $2 \mathrm{~h}$ \\
\hline & 3 & Industry and Commerce Department & $1 \mathrm{~h}$ \\
\hline & 4,5 & Social Welfare and Health Department & $3 \mathrm{~h}$ \\
\hline \multirow{3}{*}{ 3-Definition of the concepts } & 6,7 & Environment and Solid Waste Department & $3 \mathrm{~h}$ \\
\hline & 8 & Industry and Commerce Department & 1h $30 \mathrm{~min}$ \\
\hline & 9,10 & Social Welfare and Health Department & $4 \mathrm{~h}$ \\
\hline \multirow{3}{*}{ 4-Definition of the viewpoint family } & 11 & Environment and Solid Waste Department & $1 \mathrm{~h}$ \\
\hline & 12 & Industry and Commerce Department & $30 \mathrm{~min}$ \\
\hline & 13,14 & Social Welfare and Health Department & $2 \mathrm{~h}$ \\
\hline \multirow{3}{*}{ 5-Adherence test } & 15 & Environment and Solid Waste Department & $30 \mathrm{~min}$ \\
\hline & 16 & Industry and Commerce Department & $30 \mathrm{~min}$ \\
\hline & 17,18 & Social Welfare and Health Department & $1 \mathrm{~h}$ \\
\hline \multirow{3}{*}{$\begin{array}{c}\text { 6-Construction of cognitive maps and } \\
\text { clusters }\end{array}$} & 19 & Environment and Solid Waste Department & $2 \mathrm{~h}$ \\
\hline & 20 & Industry and Commerce Department & $1 \mathrm{~h} 30 \mathrm{~min}$ \\
\hline & $21,22,23,24$ & Social Welfare and Health Department & $7 \mathrm{~h}$ \\
\hline \multirow{3}{*}{$\begin{array}{l}\text { 7-Construction of hierarchical structure } \\
\text { of value }\end{array}$} & 25 & Environment and Solid Waste Department & $30 \mathrm{~min}$ \\
\hline & 26 & Industry and Commerce Department & $20 \min$ \\
\hline & 27,28 & Social Welfare and Health Department & $1 \mathrm{~h} 30 \mathrm{~min}$ \\
\hline \multirow{3}{*}{$\begin{array}{l}8 \text { - Construction of descriptors, value } \\
\text { function and identification of status quo }\end{array}$} & 29 & Environment and Solid Waste Department & $1 \mathrm{~h} 15 \mathrm{~min}$ \\
\hline & 30 & Industry and Commerce Department & $45 \min$ \\
\hline & $31,32,33$ & Social Welfare and Health Department & $4 \mathrm{~h}$ \\
\hline
\end{tabular}

The fourth stage consisted of interviewing the actors in the context in order to group the concepts (objectives) in a viewpoint family, which are understood as the strategic objectives of the decision context [18]. The fifth stage consisted of conducting interviews to an adherence test of the viewpoint family, aiming to certify that the viewpoint family built was suitably necessary and sufficient to conduct the city's sustainability management process.

The sixth stage was conducted through interviews with the actors for the purpose of preparing cognitive maps and clusters. Cognitive maps seek to create the means-end relationships between concepts (objectives) in order to explain the fundamental points of view (FPsV) and thus establish the descriptors used in performance measurement [38]. On the map, the strategic concepts are always positioned at the top and the operational ones are below them, so that the decisionmaker can get answers to the questions raised previously [39]. The objectives indicated in the central region of the map, therefore, are responsible for linking the strategic and operational objectives. In the present study, a cognitive map was elaborated for each of the FPsV.

The seventh step aimed to transition the cognitive map to the rest of the hierarchical structure of value (HSV). The beginning of HSV was carried out by defining the viewpoint family (step 4), and then was completed with the transition from the cognitive map to the rest of the HSV [38]. The eighth and last stage of the structuring of the model consisted of building ordinal descriptors (criteria) that enabled the impact of improvement actions to be verified - the reference levels (Good and Neutral) in each criterion illustrated the compromising, competitive, and excellence performance, as well as the performance measurement [21].

Once the model was built, all its descriptors (criteria) were compared with the SDGs. Considering that the SDG indicators were not designed to assess sustainable development 
on a local scale, it was prudently chosen to use the targets to assess the model's contribution to achieving global sustainable developments. Thus, it was possible to identify how the PM model can support decisionmakers in achieving global goals.

\section{Results and Discussion}

Delimiting the context and defining the actors started the construction of the PM model. The delimitation of the context lies in the fact that the city's management does not have its own (singular) performance measurement model that allows it to manage and implement actions to improve economic, environmental, and social sustainability. Additionally, considering that the model would encompass the evaluation of multiple criteria, the information generated would support the decision by aggregating the objectives and concerns of different departments. The actors were defined as follows: Decisionmakermayor; Intervening parties-responsible for the Departments of Environment, Social Welfare, Health, Solid Waste and Industry and Commerce; Acted-companies and civil society, that is, those who benefit from or suffer the consequences arising from the results of measures taken by the municipal management; Facilitator-one of the authors of the research. The role of the facilitator, based on the methodology, is to coordinate the process and fully consider the aspects identified by the decisionmaker and stakeholders as relevant to the PM model. Once the specifics of the environment and the actors in the context were identified, the problem label was defined: Assessment of the urban sustainability performance in a small town.

Then, in order to build the viewpoint family, we sought to identify the essential assessment elements in the actors' conception. For the survey of PEE, interviews were carried out with the actors, who explained their existing concerns regarding the context with respect to the management of urban sustainability. In this process, 49 PEEs were raised, which encompassed environmental, social, and economic issues, showing the multidisciplinary nature of the topic, as well as the complexity of the context. The PEEs were then legitimized through stakeholder reviews and transformed into one or more action-oriented concepts. Therefore, the actors were encouraged to comment on their desired and least desired scenario for each PEE, seeking to define their concepts with choice of preference direction and their psychologically opposite pole. In total, 79 concepts were created. As an example, we can mention the concept 2: Promote solid waste management... having an increase in solid waste pollution.

Once the construction of the action-oriented concepts was completed, they were grouped by similarity, giving rise to the viewpoint family. The viewpoint family, as it seeks to highlight the decisionmaker's strategic objectives, allowed us to confirm whether they were adequate and relevant for achieving the expected performance in the management of urban sustainability. The adherence test was applied in order to confirm whether the concepts were correctly allocated and suitably evidenced the decisionmaker's strategic objectives. Once legitimized, the viewpoint family was finalized, as shown in Figure 2.

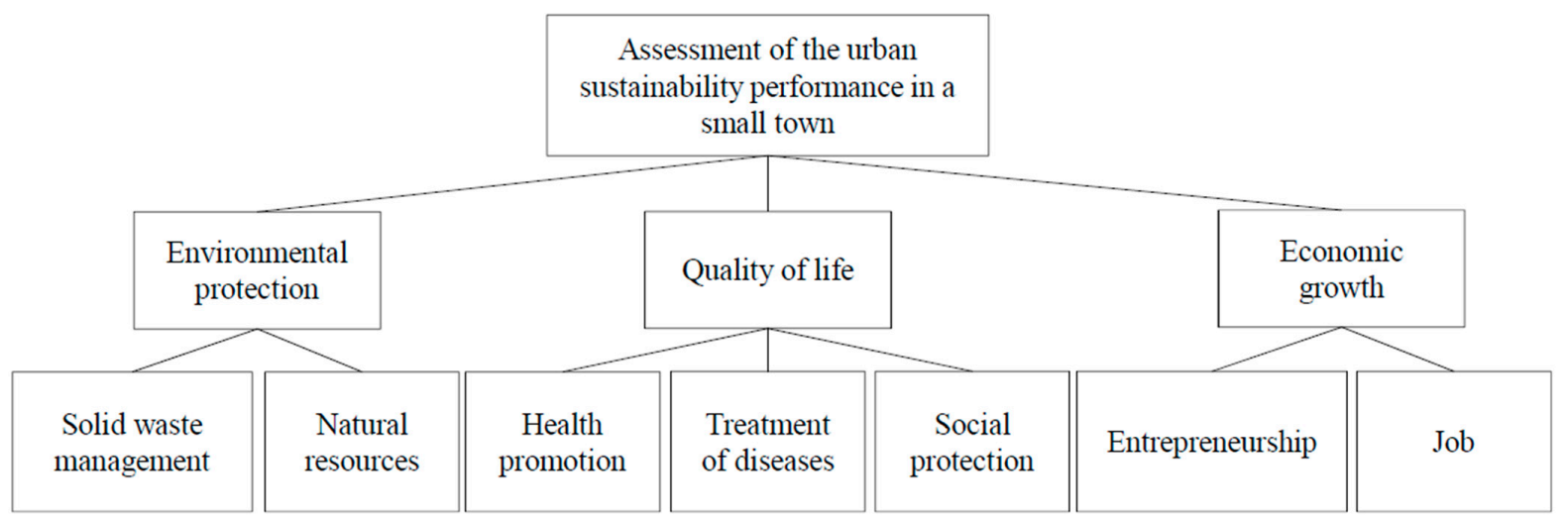

Figure 2. Viewpoints Family. 
The construction of cognitive maps took place by grouping the concepts with the purpose of highlighting the existing relationships between the concepts/objectives, that is, demonstrating the links of influence. The representation sought to clearly identify the strategic, tactical, and operational objectives. For this purpose, the concepts were divided into three dimensions: At the top of the map, the strategic objectives were placed; At the base were placed the operational objectives, that is, those that allow the measurement; In the central part were the tactical objectives. The causal relationships between the concepts were demonstrated by arrows, the concepts present in the arrow heads referred to the consequence of the concepts existing at the beginning of them.

For each FPsV, a cognitive map was created. In total, 7 cognitive maps were created, one of which is, for example, shown in Figure 3.

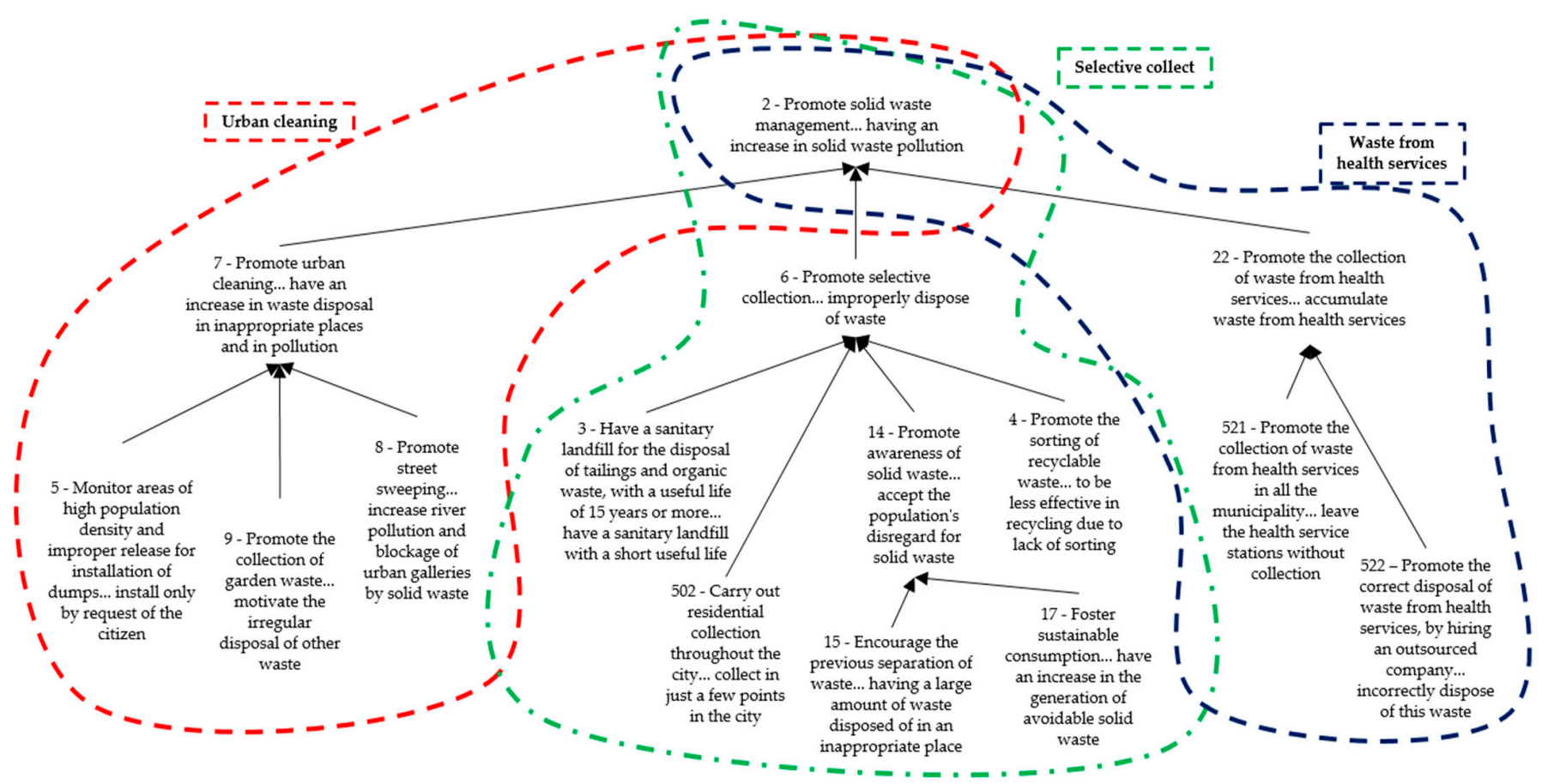

Figure 3. Cognitive Map for FPsV “Solid Waste Management”.

The construction of cognitive maps allowed the actors to build knowledge, as foreseen by the methodology, enabling the inclusion of 27 new action-oriented concepts. All concepts presented in the model with a number equal to or greater than 500 were created in the elaboration of cognitive maps, while the others were created from the concepts.

To facilitate the identification of clusters on the map, the concepts were surrounded by dotted lines. In Figure 3, the following clusters can be detected: Urban cleaning, Selective collection; Waste from health services. Continuing what guides the MCDA-C, a name was given to each concept raised in the previous stages of the model, in order to facilitate the analysis of cognitive maps. This process contributed to the transformation of clusters into a hierarchical structure of value.

In the hierarchical structure of value, the most operational elements were at the base, called elementary points of view (EPsV). The FPsV "Solid Waste Management", for example, was answered by the EPsV "Urban cleaning", "Selective collection", and "Waste from health services". Therefore, the EPsV "Urban Cleaning" was answered by dumps, garden waste collection, and street sweeping, which referred to more operational objectives. The same process was carried out with the other FPsV.

Subsequently, through an interactive process between actors and the facilitator, descriptors and their respective ordinal scales were constructed. For each element present at the base of the hierarchical structure of value, "Good" and "Neutral" reference levels were defined, with performance above the "Good" level demonstrating performance excellence 
in the criterion, below the "Neutral" level indicating that the performance is compromising, and, finally, between "Neutral" and "Good" performance, representing that the performance is competitive. The constructed criteria make it possible to assess the impact of actions on achieving the objectives.

From the descriptors and their reference levels, it was possible to verify the performance profile, that is, the current performance of the analyzed context. Figure 4 presents the descriptors constructed for the FPsV "Solid Waste Management", their respective reference levels, and the performance profile.

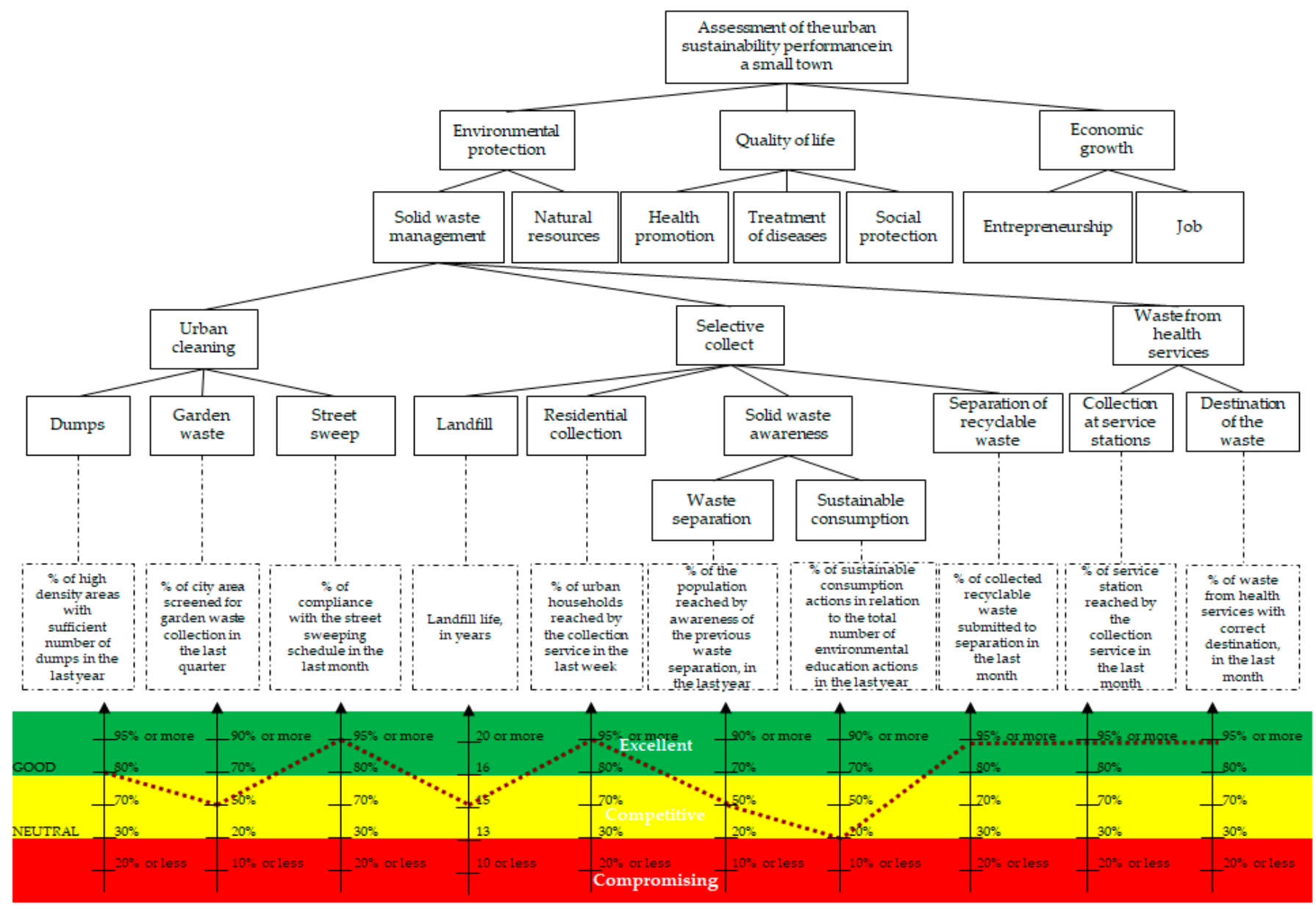

Figure 4. Descriptors, reference levels, and performance profile of the FPsV "Solid Waste Management".

In the example shown in Figure 4, it can be seen that the FPsV "Solid waste management" comprises 10 descriptors. For each descriptor, five levels in the scale were defined. The descriptor "\% of urban households reached by the collection service, in the last week", for example, received the following levels: N5-95\% or more; N4-80\%; N3-70\%; N2-30\%; N1-20\% or less. The current performance of this descriptor is excellent, as it refers to $95 \%$, as can be seen by the constant demarcation (dotted line) on the scale.

The PM model built includes a total of 66 descriptors and all of them went through the process of defining the scale levels in the criterion and identifying the performance profile. Table 2 presents the descriptors developed for the area of concern (dimension) "Environmental Protection", as well as the impact of performance on the scale. 
Table 2. Descriptors and performance profile related to the "Environmental Protection" dimension.

\begin{tabular}{|c|c|c|c|}
\hline FPsV & $\mathbf{N}^{\circ}$ & Descriptor & Performance \\
\hline \multirow{10}{*}{$\begin{array}{l}\text { Solid waste } \\
\text { management }\end{array}$} & $1-$ & $\%$ of high density areas with sufficient number of dumps in the last year & Competitive \\
\hline & 2- & $\%$ of city area screened for garden waste collection in the last quarter & Competitive \\
\hline & 3- & $\%$ of compliance with the street sweeping schedule in the last month & Excellent \\
\hline & $4-$ & Landfill life, in years & Competitive \\
\hline & $5-$ & $\%$ of urban households reached by the collection service in the last week & Excellent \\
\hline & 6- & $\begin{array}{l}\% \text { of the population reached by awareness of the previous waste } \\
\text { separation, in the last year }\end{array}$ & Competitive \\
\hline & 7- & $\begin{array}{l}\% \text { of sustainable consumption actions in relation to the total number of } \\
\text { environmental education actions in the last year }\end{array}$ & Competitive \\
\hline & 8- & $\%$ of collected recyclable waste submitted to separation in the last month & Excellent \\
\hline & 9- & $\%$ of service station reached by the collection service in the last month & Excellent \\
\hline & $10-$ & $\%$ of waste from health services with correct destination in the last month & Excellent \\
\hline \multirow{6}{*}{$\begin{array}{l}\text { Natural } \\
\text { resources }\end{array}$} & $11-$ & $\begin{array}{l}\% \text { of landowners achieved in relation to the idealized training goal in the } \\
\text { last semester }\end{array}$ & Competitive \\
\hline & $12-$ & $\begin{array}{l}\% \text { of compliance with environmental standards related to cemetery } \\
\text { management in the last year }\end{array}$ & Competitive \\
\hline & 13- & $\begin{array}{l}\% \text { of native vegetation areas reached by preservation and recovery actions } \\
\text { in the last year }\end{array}$ & Competitive \\
\hline & $14-$ & $\%$ of actions foreseen in the management plan carried out in the last year & Compromising \\
\hline & $15-$ & $\begin{array}{l}\% \text { of properties with permanent preservation area covered by awareness } \\
\text { actions in the last year }\end{array}$ & Competitive \\
\hline & $16-$ & $\begin{array}{l}\% \text { of the population reached by environmental awareness actions in the } \\
\text { last year }\end{array}$ & Competitive \\
\hline
\end{tabular}

From the performance measurement presented in Table 2, it is observed that most of the criteria for the area of concern (dimension) "Environmental Protection" presents competitive performance, that is, it is located between the levels "Good" and "Neutral" of the built scales. Through the assessment, the need for improvement can be noted, especially with regard to awareness actions in properties with permanent preservation areas, since the performance for this descriptor was below the "Neutral" level, representing a compromising performance.

Solid waste management, in addition to being considered for evaluating the urban sustainability management of the context, has been addressed in several studies, which demonstrates the importance of its evaluation. However, it is clear that the authors have different views about the metrics and factors to be evaluated. The most prominent criterion in the literature refers to the production of waste [7,9,10], although other factors are also highlighted, such as waste collection and treatment methods [33], waste sent to landfill [7,22], and urban cleaning [15]. The existence of similarities between the evaluation criteria present in the model and in the literature was noticed, although the measurement of waste production was not considered by the actors.

One of the criteria addressed by the constructed model refers to the awareness of the separation of waste by the population, demonstrating the search for active participation by civil society, who, as users of natural resources and contributors to pollution, have a significant influence on the preservation and conservation of the environment through their daily routines and decisions. Since this criterion was not found in the literature, it can be considered unique to the decision-making context of the city under study.

In relation to natural resources, among the criteria frequently addressed in the literature, we can mention water $[2,16,22,23]$ and green areas $[5,7,27]$. The constructed model, having been built considering the actors of the municipal administration, had its criteria related to management, awareness, and training, taking an approach different from that often found in the literature.

Another area of concern (dimension) present in the model is "Quality of Life". The descriptors built for it, as well as the impact of performance on the scale, are presented in Table 3. 
Table 3. Descriptors and performance profile related to the "Quality of Life" dimension.

\begin{tabular}{|c|c|c|c|}
\hline FPsV & $\mathbf{N}^{\circ}$ & Descriptor & Performance \\
\hline & $17-$ & $\begin{array}{l}\% \text { of completed patient entry and exit forms compared to total } \\
\text { completed forms in the last month }\end{array}$ & Excellent \\
\hline & $18-$ & number of committee meetings held in the last year & Competitive \\
\hline & & $\begin{array}{l}\% \text { of participation of smokers in psychological care meetings in the last } \\
\text { year }\end{array}$ & Competitive \\
\hline & $20-$ & $\begin{array}{l}\% \text { of students reached by activities on oral hygiene, in relation to the } \\
\text { total number of students registered at the municipal level, in the last } \\
\text { year }\end{array}$ & Excellent \\
\hline & $21-$ & $\begin{array}{l}\% \text { of students reached by lectures on the importance of maintaining } \\
\text { sexual and reproductive health, in relation to the total number of } \\
\text { students registered at the state level, in the last year }\end{array}$ & Competitive \\
\hline & $22-$ & $\begin{array}{l}\% \text { of participation of pregnant women in meetings, in relation to the } \\
\text { total number of pregnant women registered in SisPreNatal (Monitoring } \\
\text { System of the Humanization Program in Prenatal and Birth), in the last } \\
\text { month }\end{array}$ & Competitive \\
\hline & 23- & $\begin{array}{l}\% \text { of the population reached by the mobilization campaigns in the last } \\
\text { year }\end{array}$ & Competitive \\
\hline \multirow[t]{16}{*}{ Health promotion } & 24- & $\begin{array}{l}\text { number of fieldwork cycles against dengue carried out in the city in the } \\
\text { last year }\end{array}$ & Competitive \\
\hline & $25-$ & $\begin{array}{l}\% \text { of the population reached by the disclosure, in the last vaccination } \\
\text { campaign }\end{array}$ & Competitive \\
\hline & 26- & $\begin{array}{l}\% \text { of effectiveness of active search in relation to the number of } \\
\text { unvaccinated people in health's service station, in the last vaccination } \\
\text { campaign }\end{array}$ & Competitive \\
\hline & 27- & number of water supply sources tested in the last month & Excellent \\
\hline & $28-$ & $\%$ of city regions with one or more public academies & Excellent \\
\hline & $29-$ & $\begin{array}{l}\% \text { participation of registered users in the physical educator's classes, in } \\
\text { the last month }\end{array}$ & Competitive \\
\hline & $30-$ & $\begin{array}{l}\% \text { of children registered in the SUS (Unified Health System) with } \\
\text { monitoring of weight, in the last semester }\end{array}$ & Competitive \\
\hline & 31- & $\begin{array}{l}\text { average number of prenatal consultations carried out by pregnant } \\
\text { women registered in the Prenatal Monitoring System, in the last year }\end{array}$ & Competitive \\
\hline & $32-$ & $\%$ of comorbidities identified by medical follow-up in the last year & Competitive \\
\hline & 33- & $\begin{array}{l}\% \text { of men registered in the SUS who underwent routine exams in the } \\
\text { last year }\end{array}$ & Competitive \\
\hline & 34- & $\begin{array}{l}\% \text { of women registered in the SUS, of the recommended age group } \\
(25-64) \text {, who underwent routine exams in the last year }\end{array}$ & Competitive \\
\hline & 35- & number of quick tests performed in the last year & Competitive \\
\hline & $36-$ & $\begin{array}{l}\% \text { of drugs available in relation to the total number of drugs prescribed } \\
\text { in the last semester }\end{array}$ & Competitive \\
\hline & $37-$ & $\begin{array}{l}\% \text { of patients with diseases registered in the health protocol who } \\
\text { obtained drugs from a specialized component in the last month }\end{array}$ & Competitive \\
\hline & $38-$ & $\begin{array}{l}\% \text { of bedridden or debilitated patients who had home care in the last } \\
\text { month }\end{array}$ & Competitive \\
\hline & 39- & $\%$ of services provided in relation to total demand in the last year & Competitive \\
\hline \multirow[t]{4}{*}{ Treatment of diseases } & $40-$ & $\begin{array}{l}\% \text { of basic specialty care performed on an outpatient basis in relation to } \\
\text { the total basic specialty care, in the last year }\end{array}$ & Competitive \\
\hline & $41-$ & $\begin{array}{l}\% \text { of transport offer for OHT (Out-of-Home Treatment) in relation to } \\
\text { the need to travel, in the last year }\end{array}$ & Competitive \\
\hline & $42-$ & $\begin{array}{l}\% \text { of the demand for specialized care carried out through CONIMS } \\
\text { (Intermunicipal Health Consortium), in the last semester }\end{array}$ & Competitive \\
\hline & $43-$ & $\begin{array}{l}\% \text { of patients referred to OHT in relation to demand for OHT in the last } \\
\text { month }\end{array}$ & Competitive \\
\hline
\end{tabular}


Table 3. Cont.

\begin{tabular}{|c|c|c|c|}
\hline FPsV & $\mathbf{N}^{\circ}$ & Descriptor & Performance \\
\hline \multirow{13}{*}{ Social protection } & $44-$ & $\begin{array}{l}\% \text { of seniors registered in the CadÚnico (low-income families) who } \\
\text { participated in social activities in the last month }\end{array}$ & Competitive \\
\hline & $45-$ & $\begin{array}{l}\% \text { of children and teenagers registered in CadÚnico who participated } \\
\text { in the activities in the last month }\end{array}$ & Excellent \\
\hline & $46-$ & $\begin{array}{l}\% \text { of families registered in the CadÚnico that needed follow-up in the } \\
\text { last month }\end{array}$ & Competitive \\
\hline & $47-$ & $\begin{array}{l}\% \text { of services performed that resulted in resolution or referral, in the } \\
\text { last month }\end{array}$ & Excellent \\
\hline & $48-$ & $\begin{array}{l}\% \text { of network participation in identifying possible risk situations in the } \\
\text { last year }\end{array}$ & Excellent \\
\hline & $49-$ & $\begin{array}{l}\% \text { of care that went through social screening, in relation to the total } \\
\text { number of care provided in the last month }\end{array}$ & Excellent \\
\hline & $50-$ & $\%$ of home visits carried out in relation to demand, in the last month & Competitive \\
\hline & $51-$ & $\begin{array}{l}\% \text { of individual and family assistance in relation to demand, in the last } \\
\text { month }\end{array}$ & Excellent \\
\hline & $52-$ & $\begin{array}{l}\% \text { of individual and family assistance in relation to demand, in the last } \\
\text { month }\end{array}$ & Competitive \\
\hline & $53-$ & $\begin{array}{l}\% \text { of child and adolescent care cases met in relation to demand, in the } \\
\text { last month }\end{array}$ & Excellent \\
\hline & $54-$ & $\begin{array}{l}\% \text { of families registered in social programs in relation to CadÚnico, in } \\
\text { the last month }\end{array}$ & Excellent \\
\hline & $55-$ & $\begin{array}{l}\% \text { of temporary benefits granted in relation to demand, in the last } \\
\text { month }\end{array}$ & Competitive \\
\hline & $56-$ & $\%$ of funeral aid granted in relation to demand, in the last month & Excellent \\
\hline
\end{tabular}

In the area of concern (dimension) "Quality of Life", which is related to the social dimension of sustainability, it is clear that competitive performance is observed in most criteria. The performance is better for the viewpoint family "Social Protection", reflecting the attention paid to meeting the needs of the less favored classes. Another finding is related to the high number of criteria built for this area of concern, which refers to the characteristic of a PM model adopted to assess the sustainable development of a city. According to [6], social factors are highlighted when it comes to promoting local sustainability.

Most of the model's descriptors refer to the health component, represented by the viewpoint family "Health Promotion" and "Treatment of Diseases". In the literature, it is possible to find some equivalent evaluation criteria, such as the participation in sports activities in parks and swimming pools [22], childhood obesity [7], people at risk of poverty after social transfers [29], home health services, and collective and family activities [15]. Although the same metrics have not been used, they seek to assess issues similar to those assessed by the model.

Finally, Table 4 presents the descriptors, as well as the impact of performance on the scale in relation to the area of concern (dimension) "Economic Growth".

From Table 4, it can be noted, that the performance of the area of concern (dimension) "Economic growth" also presents a competitive performance in most criteria. The reduced number of criteria is a recurrent issue in the economic dimension. The authors of [7], after surveying indicators present in 18 indexes and 7 indicator systems, identified that economic indicators had the smallest number of indicators, representing only $14 \%$ of the total.

A singularity identified in this portion of criteria concerns the creation of a criterion to measure the support for the management of the collectors' cooperative. The incentive to maintain the collectors' cooperative, in the view of the actors, is justified by the improvement in the income and quality of life of the collectors, because, if they were not linked to the cooperative, they would start working in precarious conditions and would lose the benefit of the division of tasks and teamwork. 
Table 4. Descriptors and Performance Profile Related to the "Economic Growth" Dimension.

\begin{tabular}{|c|c|c|c|}
\hline FPsV & $\mathbf{N}^{\circ}$ & Descriptor & Performance \\
\hline \multirow{7}{*}{ Entrepreneurship } & 57- & $\%$ of meeting demands for business formalization in the last year & Excellent \\
\hline & $58-$ & $\%$ of credit requests approved in relation to the total requests in the last year & Competitive \\
\hline & 59- & $\%$ of service requests fulfilled in the last year & Competitive \\
\hline & $60-$ & $\%$ of occupation of public goods destined to enterprises, in the last year & Excellent \\
\hline & 61- & $\begin{array}{l}\% \text { of benefited enterprises that remain active and with the same number of } \\
\text { jobs after } 5 \text { years }\end{array}$ & Competitive \\
\hline & $62-$ & $\%$ of job vacancies, reports in reports, filled, in the last month & Excellent \\
\hline & $63-$ & $\begin{array}{l}\% \text { of course utilization, in relation to the number of available places, in the last } \\
\text { year }\end{array}$ & Competitive \\
\hline \multirow[t]{3}{*}{ Job } & $64-$ & $\begin{array}{l}\% \text { of people in the labor market in relation to the number of motivation and } \\
\text { personal valuation visits carried out in the last year }\end{array}$ & Competitive \\
\hline & $65-$ & $\begin{array}{l}\text { number of visits to support the management of the collectors' cooperative in } \\
\text { the last year }\end{array}$ & Competitive \\
\hline & $66-$ & $\begin{array}{l}\% \text { of cooperative collectors in relation to the total number of collectors in the } \\
\text { last year }\end{array}$ & Competitive \\
\hline
\end{tabular}

Another issue unique to the model can be noted through the descriptor 64, which seeks to identify the percentage of people in the market in relation to the number of visits made. According to the decisionmaker, motivational and personal valuing visits are carried out for low-income people, who are unemployed due to a lack of confidence or because they feel incapable. This criterion is, therefore, intended to identify whether the approach has been positive, enabling an increase in the income of this portion of the population.

The performance evaluation model designed to assess the sustainability of a small Brazilian city contributes to gaps identified in the literature, especially in the absence of multi-criteria decision support models focused on small cities. The model developed can be used as an example by other small cities, as long as it is adjusted to their context, and allows for the elaboration and evaluation of public policies with a focus on sustainability.

With the construction of the model, and based on the evaluation of the city's current sustainable development performance, the first objective of the research was completed. The survey also sought to identify the local contribution to monitoring the achievement of the SDGs, based on the constructed model. Thus, the evaluation criteria present in the model were compared with the goals of the SDGs.

It was noted that, of the SDGs that appear as the highest recurrence, when related to the evaluation criteria present in the model, are the SDGs: 1 (no poverty); 3 (good health and well-being); 8 (decent work and economic growth); 11 (sustainable cities and communities); 16 (peace, justice, and strong institutions). Figure 5 represents the adherence of the evaluation criteria present in the model to the SDGs, with the numbers inserted inside the graph corresponding to the descriptors presented in Tables 2-4.

The criteria related to the SDG 1, no poverty, are present in the area of concern called "Quality of Life", which makes up the FPsV "Social Protection". As can be seen from its name, this FPsV seeks to assess the performance of socioeconomic aspects related to the actions of social assistance in the city, in the sense of preventing risky situations and meeting vulnerabilities.

In the area of concern "Quality of Life", is also recurrent in SDG 3, relating to good health and well-being. The criteria that contribute to achieving these goals are those arising from the FPsV "Health Promotion" and "Treatment of Diseases". Considering the amount of these SDGs that were listed, it is clear that they refer to issues relevant to the management of urban sustainability in this city.

Another SDG that has generated a considerable number of relationships between its goals and the model's evaluation criteria was SDG 8-decent work and economic growth. The goals of this are linked to the models' area, called "Economic growth". This area refers to concerns about the generation of work and income, being, therefore, aimed at citizens and businesses. 


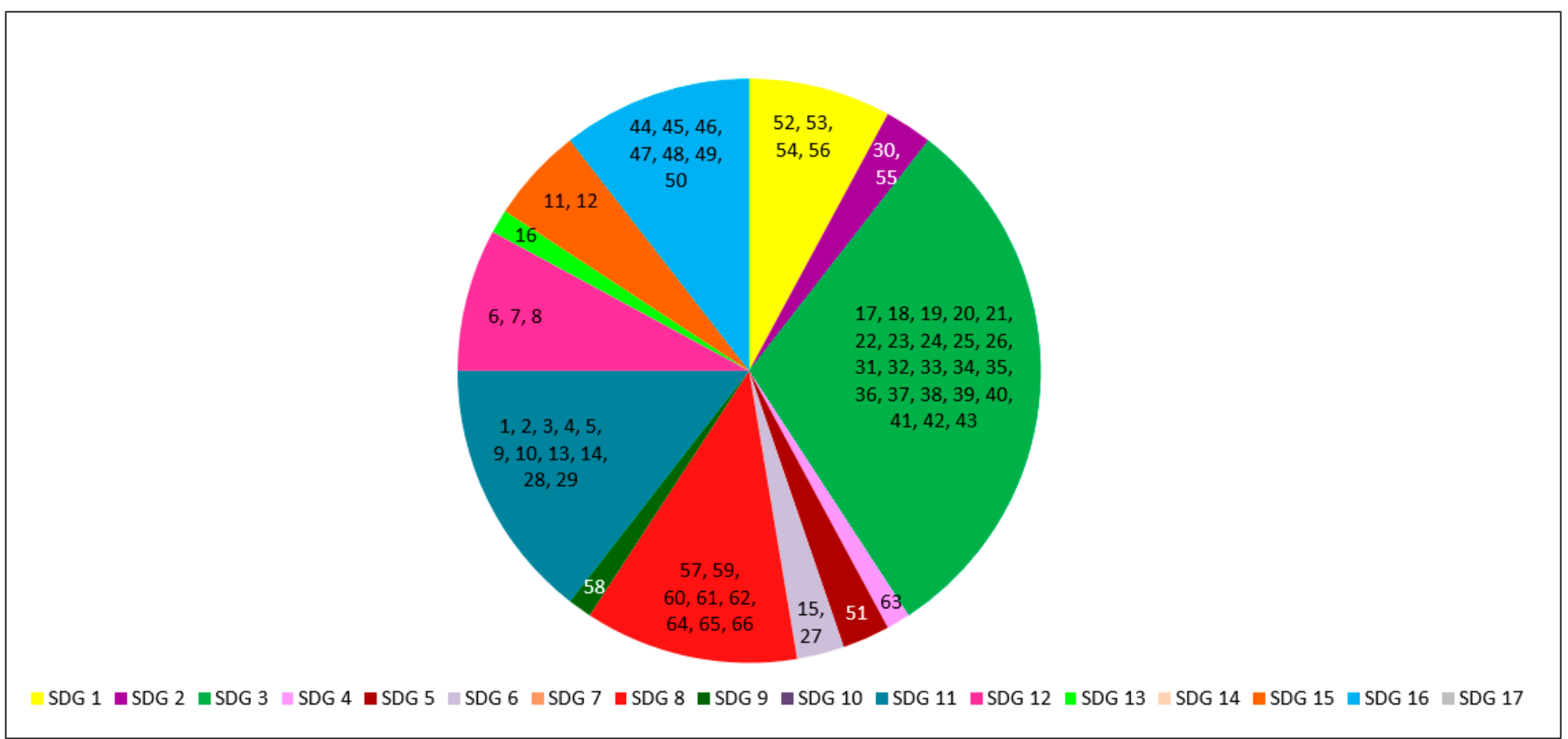

Figure 5. The evaluation criteria covered by the model and the goals of the SDGs.

SDG 11, or sustainable cities and communities, was also relevant for PM at the local level. However, some of its goals have approaches that do not apply at the local scale, such as the support between countries and national and global planning. As for the goals of SDG 16-peace, justice, and strong institutions - its goals are to reduce violence, promote equal rights, and develop strong institutions, among others, which are linked to the evaluation criteria deriving from the FPsV "Social protection".

From the qualitative confrontation between the evaluation criteria addressed in the constructed model and the goals of the SDG, it can be seen that the objectives of managing the city's urban sustainability are partially aligned with the objectives pursued at a global level. This can be confirmed, as some SDG were not identified among the concerns of local management, namely SDGs 7 (affordable and clean energy), 10 (reduced inequalities), 14 (life below water), and 17 (partnerships for the goals).

The fact that these SDG are not related to the evaluation criteria used in the PM model does not make it unfeasible, as the confrontation serves to demonstrate that a good performance in local objectives generates positive results for the achievement of some of the global goals of sustainable development. Furthermore, considering that the PM model was built to provide support to the actors, it has fulfilled the objective, since it started from their values and preferences, as provided for in the MCDA-C methodology.

\section{Conclusions}

The research had theoretical and practical implications. The theoretical contribution refers to the construction of a PM model of urban sustainable development designed specifically for the context in which it was applied, according to the values and preferences of the actors, to whom the model supports decision-making. Another contribution concerns the expansion of the scope of criteria used for the PM of urban sustainable development, since, given its constructivist stance, the model presents new criteria to be used for this purpose, and such evaluation criteria can serve as a basis for evaluating the sustainability performance of other cities of a similar size, provided that appropriate adaptations are made to the context.

As for the practical implications, as the MCDA-C methodology was used, the actors expanded their knowledge on the subject during the process of building the PM model and began to realize how actions reflect on performance. Furthermore, considering that several departments were involved in the process, the actors were able to notice the 
relationship between them and how the performance of expertise area contributes to the overall performance.

Another practical contribution refers to the supporting of the decision and evaluation of public policies with a focus on sustainability, a topic that has been much debated globally and which still has gaps in terms of its evaluation and monitoring.

When evaluating the performance profile of the 66 descriptors constructed, it was noted that 45 of them presented competitive performance, being situated between the "Good" and "Neutral" levels of the elaborated criteria, while 20 presented excellent performance, above the good level, and 1 presented compromising performance, representing an urgent need for attention. Considering this information, it can be qualitatively affirmed that the current performance of the city's urban sustainability management is competitive, although there is a possibility for improvement in several criteria.

When evaluating the global sustainability performance of countries located on five continents, [26] had already identified that the Americas had a reasonable performance. The results of the current research came to confirm this finding in relation to Brazil, showing that there is still a lot to improve to reach the ideal sustainable performance. In addition, knowing that the country is mostly made up of small cities, building performance evaluation models are essential, as they constitute a decision support instrument, allowing decisionmakers to monitor the evolution and identify areas that require more attention.

Knowing that local performance reflects on global performance, we sought to understand how the evaluation criteria adopted by the model were related to the SDGs. For that, the adherence of these criteria to the goals of the SDG was verified. Based on these findings, it is clear that the built model, in addition to providing decision support information, and by allowing the decisionmaker to monitor the progress of the city's urban sustainability management towards the objectives of the context, helps to achieve a larger, globally targeted objective.

This research has some limitations: (i) The PM model has unique aspects, having been built according to the values of decisionmakers and the particularities of the city under study, not being valid for application in a different context without adaptations; (ii) The model had a partial coverage of the city's urban sustainability management departments.

The use of sustainability performance assessment models, such as the MCDA-C, represents a path to accelerating the achievement of the global sustainability objective, which is relevant in the current scenario. Thus, it is suggested for future research: (i) The construction of constructivist PM models for other contexts, such as regions and states; (ii) The continuity of research to complement the built PM model, since it is a wide area with a possibility for the aggregation of criteria; (iii) The implementation and use of the model in managing the sustainability of the object city of this study, with the purpose of carrying out longitudinal studies.

Author Contributions: Conceptualization, F.C.C., S.C.B., E.P.d.L. and S.E.G.d.C.; sustainable indicators and sustainable development, E.P.d.L.; municipalities operations services, S.E.G.d.C.; methodology development, F.C.C. and S.C.B.; formal analysis, F.C.C. and S.C.B.; data curation, F.C.C. and S.C.B.; writing-original draft preparation, F.C.C.; writing-review and editing, S.C.B., E.P.d.L. and S.E.G.d.C.; visualization, F.C.C., S.C.B., E.P.d.L. and S.E.G.d.C.; supervision, S.C.B.; performance assessment and MCDA-C, F.C.C. and S.C.B.; funding acquisition, S.C.B., E.P.d.L. and S.E.G.d.C. All authors have read and agreed to the published version of the manuscript.

Funding: This research received no external funding.

Institutional Review Board Statement: Not applicable.

Data Availability Statement: Data sharing not applicable.

Acknowledgments: The authors are grateful to Universidade Tecnológica Federal do Paraná (UTFPR)—Câmpus Pato Branco for the financial support.

Conflicts of Interest: The authors declare no conflict of interest. 


\section{References}

1. Ghalib, A.; Qadir, A.; Ahmad, S.R. Evaluation of Developmental Progress in Some Cities of Punjab, Pakistan, Using Urban Sustainability Indicators. Sustainability 2017, 9, 1473. [CrossRef]

2. Xu, C.; Wang, S.; Zhou, Y.; Wang, L.; Liu, W. A Comprehensive Quantitative Evaluation of New Sustainable Urbanization Level in 20 Chinese Urban Agglomerations. Sustainability 2016, 8, 91. [CrossRef]

3. Visvaldis, V.; Ainhoa, G.; Ralfs, P. Selecting Indicators for Sustainable Development of Small Towns: The Case of Valmiera Municipality. Procedia Comput. Sci. 2013, 26, 21-32. [CrossRef]

4. WCED (World Commission on Environment and Development). Our Common Future; Oxford University Press: Oxford, UK, 1987.

5. Sun, X.; Liu, X.; Li, F.; Tao, Y.; Song, Y. Comprehensive evaluation of different scale cities' sustainable development for economy, society, and ecological infrastructure in China. J. Clean. Prod. 2017, 163, S329-S337. [CrossRef]

6. Salvati, L.; Carlucci, M. A composite index of sustainable development at the local scale: Italy as a case study. Ecol. Indic. 2014, 43, 162-171. [CrossRef]

7. Feleki, E.; Vlachokostas, C.; Moussiopoulos, N. Characterisation of sustainability in urban areas: An analysis of assessment tools with emphasis on European cities. Sustain. Cities Soc. 2018, 43, 563-577. [CrossRef]

8. Almeida, A.C.L.; Smart, J.; Davey, P. Can Learned Experiences Accelerate the Implementation of Sustainable Development Goal 11? A Framework to Evaluate the Contributions of Local Sustainable Initiatives to delivery SDG 11 in Brazilian Municipalities. Eur. J. Sustain. Dev. 2018, 7, 517-530. [CrossRef]

9. Fitzgerald, B.; O'Doherty, T.; Moles, R.; O’Regan, B. A quantitative method for the evaluation of policies to enhance urban sustainability. Ecol. Indic. 2012, 18, 371-378. [CrossRef]

10. Valcárcel-Aguiar, B.; Murias, P.; Rodríguez-González, D. Sustainable Urban Liveability: A Practical Proposal Based on a Composite Indicator. Sustainability 2018, 11, 86. [CrossRef]

11. United Nations. The Millennium Development Goals Report. 2015. Available online: https://nacoesunidas.org/wp-content/ uploads/2015/07/MDG-2015-June-25.pdf (accessed on 6 June 2020).

12. Allen, C.; Nejdawi, R.; El-Baba, J.; Hamati, K.; Metternicht, G.; Wiedmann, T. Indicator-based assessments of progress towards the sustainable development goals (SDGs): A case study from the Arab region. Sustain. Sci. 2017, 12, 975-989. [CrossRef]

13. Kawakubo, S.; Murakami, S.; Ikaga, T.; Asami, Y. Sustainability assessment of cities: SDGs and GHG emissions. Build. Res. Inf. 2017, 46, 528-539. [CrossRef]

14. Neely, A.D. The performance measurement revolution: Why now and what next? Int. J. Oper. Prod. Manag. 1999, 19, 205-228. [CrossRef]

15. Faria, P.A.; Ferreira, F.A.; Jalali, M.S.; Bento, P.; António, N.J. Combining cognitive mapping and MCDA for improving quality of life in urban areas. Cities 2018, 78, 116-127. [CrossRef]

16. Gonzalez-Garcia, S.; Manteiga, R.; Moreira, M.T.; Feijoo, G. Assessing the sustainability of Spanish cities considering environmental and socio-economic indicators. J. Clean. Prod. 2018, 178, 599-610. [CrossRef]

17. Nudurupati, S.S.; Bititci, U.S.; Kumar, V.; Chan, F.T. State of the art literature review on performance measurement. Comput. Ind. Eng. 2011, 60, 279-290. [CrossRef]

18. Martins, P.; Pinheiro de Lima, E.; Bortoluzzi, S.C.; Gouvea Da Costa, S.E. Performance assessment of the operations strategy of credit unions. Int. J. Product. Perform. Manag. 2021, in press. [CrossRef]

19. Lacerda, R.; Ensslin, L.; Ensslin, S.R. Research opportunities in strategic management field: A performance measurement approach. Int. J. Bus. Perform. Manag. 2014, 15, 158. [CrossRef]

20. Huang, L.; Wu, J.; Yan, L. Defining and measuring urban sustainability: A review of indicators. Landsc. Ecol. 2015, 30, 1175-1193. [CrossRef]

21. Bana, E.; Costa, C.A.; Stewart, T.J.; Vansnick, J. Multicriteria decision analysis: Some thoughts based on the tutorial and discussion sessions of the ESIGMA meetings. Eur. J. Oper. Res. 1997, 99, 28-37. [CrossRef]

22. Tanguay, G.A.; Rajaonson, J.; Lefebvre, J.-F.; Lanoie, P. Measuring the sustainability of cities: An analysis of the use of local indicators. Ecol. Indic. 2010, 10, 407-418. [CrossRef]

23. Van Leeuwen, C.J.; Frijns, J.; Van Wezel, A.; Van De Ven, F.H.M. City Blueprints: 24 Indicators to Assess the Sustainability of the Urban Water Cycle. Water Resour. Manag. 2012, 26, 2177-2197. [CrossRef]

24. Meijering, J.V.; Tobi, H.; Kern, K. Defining and measuring urban sustainability in Europe: A Delphi study on identifying its most relevant components. Ecol. Indic. 2018, 90, 38-46. [CrossRef]

25. Moussiopoulos, N.; Achillas, C.; Vlachokostas, C.; Spyridi, D.; Nikolaou, K. Environmental, social and economic information management for the evaluation of sustainability in urban areas: A system of indicators for Thessaloniki, Greece. Cities 2010, 27, 377-384. [CrossRef]

26. Shen, L.; Shuai, C.; Jiao, L.; Tan, Y.; Song, X. A Global Perspective on the Sustainable Performance of Urbanization. Sustainability 2016, 8, 783. [CrossRef]

27. Zhang, L.; Xu, Y.; Yeh, C.-H.; Liu, Y.; Zhou, D. City sustainability evaluation using multi-criteria decision making with objective weights of interdependent criteria. J. Clean. Prod. 2016, 131, 491-499. [CrossRef]

28. Caldatto, F.C.; Bortoluzzi, S.C.; De Lima, E.P. The role of public administration in sustainable development. In International Business, Trade and Institutional Sustainability; World Sustainability Series; Springer: Cham, Switzerland, 2020; pp. 69-79. 
29. Antanasijević, D.; Pocajt, V.; Ristić, M.; Perić-Grujić, A. A differential multi-criteria analysis for the assessment of sustainability performance of European countries: Beyond country ranking. J. Clean. Prod. 2017, 165, 213-220. [CrossRef]

30. Xu, X.; Gao, J.; Zhang, Z.; Fu, J. An Assessment of Chinese Pathways to Implement the UN Sustainable Development Goal-11 (SDG-11)_A Case Study of the Yangtze River Delta Urban Agglomeration. Int. J. Environ. Res. Public Health 2019, 16, 2288. [CrossRef]

31. Gogate, N.G.; Kalbar, P.; Raval, P.M. Assessment of stormwater management options in urban contexts using Multiple Attribute Decision-Making. J. Clean. Prod. 2017, 142, 2046-2059. [CrossRef]

32. Oses, U.; Rojí, E.; Cuadrado, J.; Larrauri, M. Multiple-Criteria Decision-Making Tool for Local Governments to Evaluate the Global and Local Sustainability of Transportation Systems in Urban Areas: Case Study. J. Urban Plan. Dev. 2018, 144, 04017019. [CrossRef]

33. Rodrigues, A.P.; Fernandes, M.L.; Rodrigues, M.F.F.; Bortoluzzi, S.C.; Da Costa, S.G.; De Lima, E.P. Developing criteria for performance assessment in municipal solid waste management. J. Clean. Prod. 2018, 186, 748-757. [CrossRef]

34. Ensslin, S.R.; Ensslin, L.; Back, F.; Lacerda, R.T.d.O. Improved decision aiding in human resource management. Int. J. Product. Perform. Manag. 2013, 62, 735-757. [CrossRef]

35. IBGE. Instituto Brasileiro de Geografia e Estatistica. 2010. Available online: https://www.ibge.gov.br/estatisticas/sociais/ populacao/2098-np-censo-demografico/9662-censo-demografico-2010.html?edicao=9673\&t=destaques (accessed on 13 August 2021).

36. IBGE. Instituto Brasileiro de Geografia e Estatistica. 2010. Available online: https://cidades.ibge.gov.br/brasil/pr/coronelvivida/pesquisa/36/30246?tipo=cartograma (accessed on 13 August 2021).

37. Lacerda, R.T.d.O.; Ensslin, L.; Ensslin, S.R. A performance measurement framework in portfolio management. Manag. Decis. 2011, 49, 648-668. [CrossRef]

38. Ensslin, L.; Dutra, A.; Ensslin, S.R. MCDA: A constructivist approach to the management of human resources at a governmental agency. Int. Trans. Oper. Res. 2000, 7, 79-100. [CrossRef]

39. Longaray, A.A.; Ensslin, L.; Ensslin, S.R.; Da Rosa, I.O. Assessment of a Brazilian public hospital's performance for management purposes: A soft operations research case in action. Oper. Res. Health Care 2015, 5, 28-48. [CrossRef] 